\title{
Uji Validitas Konstruk Pada Instrumen Self-Esteem Inventory Dengan Metode Confirmatory Factor Analysis (CFA)
}

\author{
Nadidah Zahrani \\ UIN Syarif Hidayatullah Jakarta \\ didah_zahra@gmail.com
}

\begin{abstract}
Self-esteem is a reflection of human nature in psychology to see how a person decides the behavior that sorted into 3 dimensions, that is feeling towards self, feeling toward others and relationship with others. Self-esteem inventory is a standard measurement instrument used to measure the 3 dimensions of self-esteem that developed by Michinton (1993). The purpose of this research is to test the construct validity of the instrument. The data of this research collected from 208 smartphone users that have been using smartphone for more than a year. Method that used to test this research is confirmatory factor analysis (CFA) with LISREL 8.70. The results showed that all the items that consist of 25 items is undimensional. That means, all the items just measure one factor model that has been theorized by Self-esteem Inventory can be accepted.
\end{abstract}

Keyword: Self-esteem, Feeling Toward Self, Feeling Toward Others and Relationship with Others, Confirmatory Factor Analysis

\begin{abstract}
Abstrak
Self-esteem adalah suatu cerminan sifat manusia dalam ilmu psikologi untuk melihat bagaimana seseorang menentukan perilakunya yang tersusun dalam tiga buah dimensi yaitu perasaan mengenai diri sendiri, perasaan mengenai orang lain dan hubungan dengan orang lain. Self-esteem Inventory merupakan instrumen pengukuran baku yang digunakan untuk mengukur tiga dimensi self-esteem yang dikembangkan oleh Michinton (1993). Penelitian ini bertujuan untuk menguji validitas kostruk instrumen tersebut. Data dalam penelitian ini diperoleh dari pengguna smartphone yang sudah menggunakan smartphone-nya lebih dari 1 tahun yang berjumlah 208 orang. Metode yang digunakan untuk mengujinya adalah confirmatory factor analysis (CFA) menggunakan software LISREL 8.70. Hasil dari penelitian ini menunjukkan bawa seluruh item yang berjumlah 25 item bersifat unidimensional. Artinya seluruh item hanya mengukur satu faktor saja sehingga model satu faktor yang diteorikan dalam Self-esteem Inventory dapat diterima.
\end{abstract}

Kata kunci: Harga Diri, Perasaan Mengenai Diri Sendiri, Perasaan Mengenai Orang Lain dan Hubungan dengan Orang Lain, Analisis Faktor Konfirmatorik

Diterima: 20 Agustus 2015 Direvisi: 9 September 2015 Disetujui: 16 September 2015 


\section{PENDAHULUAN}

Pada tahun 1993 Michinton muncul sebagai orang yang menggunakan istilah "Self-esteem" untuk mendeskripsikan bagaimana seseorang menilai dirinya melihat self-esteem yang ada dalam diri individu tersebut. Self-esteem merupakan peranan penting pada individu dalam menentukan perilaku dan memandang atau menilai dirinya sendiri yang tampak dari perilaku sebelumnya yang diujur melalui tiga dimensi. Tiga dimensi self-esteem tersebut terdiri dari perasaan mengenai diri sendiri, perasaan mengenai hidup, dan hubungan dengan orang lain (Michinton, 1993).

(a) Perasaan mengenai diri sendiri. Orang yang memiliki self-esteem yang tinggi akan menerima diri sendiri tanpa syarat serta menghargai nilai diri sendiri sebagai manusia. Sedangkan orang yang memiliki self-esteem yang rendah akan kurang menghargai dirinya sendiri dengan meyakini penilaian pribadinya yang secara langsung menilai pencapaiannya.

(b) Perasaan mengenai hidup. Jika seseorang memiliki self-esteem yang tinggi maka orang tersebut akan bertanggung jawab dan berlapang dada atas setiap bagian hidup yang dijalani. Tetapi orang yang memiliki self-esteem yang rendah dalam kehidupan dan apa yang terjadi didalam hidupnya sering kali terlihat tak terkendali.

(c) Hubungan dengan orang lain. Orang yang memiliki self-esteem yang tinggi dapat bertoleransi dan memberikan penghargaan yang sama terhadap semua orang, meyakini bahwa setiap orang termasuk dirinya mempunyai hak yang sama. Sedangkan orang yang memiliki self-esteem yang rendah pada dasarnya akan kurang menghargai orang lain. Tidak toleransi terhadap orang lain dan meyakinkan bahwa orang lain harus hidup dengan caranya. 


\section{Deskripsi Mengenai Instrumen}

Michinton (1993) mengembangkan dan memvalidasi suatu instrumen pengukuran yang dinamakan self-esteem inventory untuk mengukur ketiga dimensi self-esteem (perasaan mengenai diri sendiri, perasaan mengenai hidup, hubungan dengan orang lain). Instrumen ini terdiri atas 25 item dimana tiap dimensi memiliki jumlah item yang berbeda. Terdapat 16 item favorable dan 9 item unfavorable. Contoh item self-esteem inventory adalah sebagai berikut:

\section{Tabel 1}

Item-Item Self-Esteem Inventory

\begin{tabular}{cc}
\hline No & \multicolumn{1}{c}{ Item } \\
\hline 1 & I accept myself fully just as I am \\
2 & I believe others behave as they do for good reasons \\
\hline
\end{tabular}

Dikarenakan adanya perbedaan bahasa yang digunakan oleh subjek dalam penelitian ini, peneliti melakukan proses adaptasi terlebih dahulu terhadap instrumen pengukuran tersebut. Adapun contoh hasil dari adaptasi sebagai berikut.

\section{Tabel 2}

Item-Item Self-Esteem Inventory (Adaptasi)

\begin{tabular}{cc}
\hline No & Item \\
\hline 1 & Saya menyukai diri saya sendiri \\
2 & Saya yakin orang lain melakukan sesuatu dengan maksud yang baik \\
\hline
\end{tabular}

Self-esteem inventory yang asli memiliki empat kategori jawaban, yaitu: I always do, I usually do, I occasionally do, I never do, dan peneliti mengadaptasinya ke dalam Bahasa Indonesia menjadi: "Sangat Setuju” (SS), "Setuju" (S), "Tidak Setuju" (TS), "Sangat Tidak Setuju” (STS). Untuk penyekorannya hanya memberikan penilaian tertinggi pada pernyataan "Sangat Setuju" (SS) dan terendah pada pilihan "Sangat Tidak Setuju" (STS) untuk 
pernyataan favorable. Untuk penyekoran item unfavorable, penilaian tertinggi pada pernyataan "Sangat Tidak Setuju" (STS) dan terendah pada pilihan "Sangat Setuju" (SS). Skor-skor tersebut kemudian dihitung, dengan proporsi item yang yang bersifat favorable dengan ketentuan sebagai berikut: $\mathrm{SS}=4, \mathrm{~S}=3, \mathrm{TS}=2$, $\mathrm{STS}=1$. Untuk item yang bersifat unfavorable dihitung dengan ketentuan sebagai berikut: $\mathrm{SS}=1, \mathrm{~S}=2, \mathrm{TS}=3, \mathrm{STS}=4$.

\section{METODE}

Untuk menguji validitas konstruk instrumen pengukuran self-esteem inventory ini menggunakan pendekatan analisis faktor berupa confirmatory factor analysis (CFA). Pengujian analisis CFA seperti ini dilakukan dengan bantuan software LISREL 8.70 (Joreskog \& Sorbom, 1999).

Adapun logika dari CFA (Umar, 2011) adalah sebagai berikut:

1. Bahwa ada sebuah konsep atau trait berupa kemampuan yang didefinisikan secara operasional sehingga dapat disusun pertanyaan atau pernyataan untuk mengukurnya. Kemampuan ini disebut faktor, sedangkan pengukuran terhadap faktor ini dilakukan melalui analisis terhadap respon atas itemitemnya.

2. Diteorikan setiap item hanya mengukur satu faktor saja, begitupun juga tiap subtes hanya mengukur satu faktor juga. Artinya baik item maupun subtes bersifat unidimensional.

3. Dengan data yang tersedia dapat digunakan untuk mengestimasi matriks korelasi antar item yang seharusnya diperoleh jika memang unidimensional. Matriks korelasi ini disebut sigma $(\Sigma)$, kemudian dibandingkan dengan matriks dari data empiris, yang disebut matriks S. Jika teori tersebut benar (unidemensional) maka tentunya tidak ada perbedaan antara matriks $\sum$ matriks $\mathrm{S}$ atau bisa juga dinyatakan dengan $\sum-\mathrm{S}=0$.

4. Pernyataan tersebut dijadikan hipotesis nihil yang kemudian diuji dengan chisquare. Jika hasil chi-square tidak signifikan ( $\mathrm{p}>0.05$ ), maka hipotesis nihil 
tersebut "tidak ditolak". Artinya teori unidimensionalitas tersebut dapat diterima bahwa item ataupun sub tes instrumen hanya mengukur satu faktor saja. Sedangkan, jika nilai chi-square signifikan ( $\mathrm{p}<0.05)$, artinya bahwa item tersebut mengukur lebih dari satu faktor atau bersifat multidimensional. Maka perlu dilakukan modifikasi terhadap model pengukuran.

5. Adapun dalam memodifikasi model pengukuran dilakukan dengan cara membebaskan parameter berupa korelasi kesalahan pengukuran. Hal ini terjadi ketika suatu item mengukur selain faktor yang hendak diukur. Setelah beberapa kesalahan pengukuran dibebaskan untuk saling berkorelasi, maka akan diperoleh model yang fit, maka model terakhir inilah yang akan digunakan pada langkah selanjutnya.

6. Jika model fit, maka langkah selanjutnya menguji apakah item signifikan atau tidak mengukur apa yang hendak diukur, dengan yang hendak di ukur, dengan menggunakan $t$-test. Jika hasil $t$-test tidak signifikan $(\mathrm{t}<1,96)$ maka item tersebut tidak signifikan dalam mengukur apa yang hendak diukur, bila perlu item yang demikian dieliminasi dan sebaliknya.

7. Selain itu, apabila dari hasil CFA terdapat item yang koefisien muatan faktornya negative, maka item tersebut juga harus didrop. Sebab hal ini tidak sesuai dengan sifat item, yang bersifat positif (favorable).

8. Kemudian, apabila terdapat korelasi parsial atau kesalahan pengukuran item terlalu banyak berkorelasi dengan kesalahan pengukuran lainnya, maka item tersebut akan dieliminasi. Sebab, item yang demikian selain mengukur apa yang hendak diukur, ia juga mengukur hal lain (multidimensi). Adapun asumsi didrop atau tidaknya item adalah jika tidak terdapat lebih dari tiga korelsi parsial atau kesalahan pengukuran yang berkorelasi dengan item lainnya.

9. Terakhir, setelah dilakukan langkah-langkah seperti yang telah disebutkan di atas. Dan mendapatkan item dengan muatan faktor signifikan $(t>1.96)$ dan positif. Maka, selanjutnya item-item yang signifikan ( $\mathrm{t}>1.96)$ dan positif tersebut diolah untuk nantinya didapatkan faktor skornya. 
Adapun data dalam penelitian ini diambil dari pengguna smartphone yang telah menggunakan smartphone nya minimal 1 tahun yang berjumlah 208 orang. Data tersebut dikumpulkan dalam rangka penyusunan skripsi (Zahrani, 2014).

\section{HASIL}

Penulis menguji apakah 10 item perasaan mengenai diri sendiri yang ada bersifat unidimensional, artinya benar hanya mengukur faktor yang dilakukan dengan model satu faktor, ternyata tidak fit, dengan chi-square $=89,14, \mathrm{df}=35, \mathrm{P}$-value $=0.00000$, dan nilai RMSEA $=0.086$. Oleh sebab itu, penulis melakukan modifikasi terhadap model, dimana kesalahan pengukuran pada beberapa item dibebaskan berkorelasi satu sama lainnya seperti pada gambar 1 berikut ini.

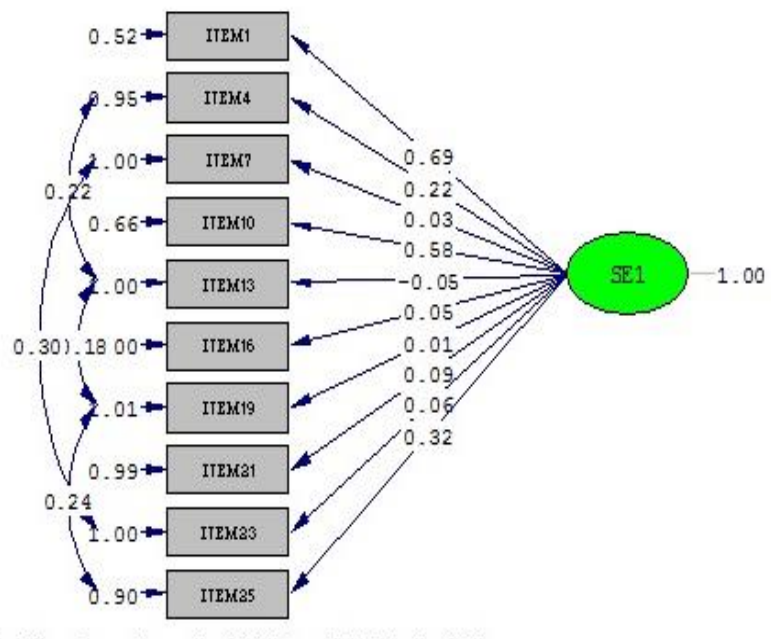

Chi-Square $=41.47, \mathrm{df}=31, \mathrm{P}-\mathrm{value}=0.09908, \mathrm{RMSEA}=0.040$

\section{Gambar 1}

Analisis Faktor Konfirmatorik Self-Esteem Inventori Dimensi Perasaan Mengenai Diri Sendiri

Dari gambar 1 diatas, maka dapat diperoleh model fit dengan chi-square $=41.47, \mathrm{df}=31, P$-value $=0.09908, \mathrm{RMSEA}=0.040$. Nilai chi-square 
menghasilkan $P$-value $>0.05$ (tidak siginfikan), yang artinya model dengan satu faktor (unidimensional) dapat diterima, dimana seluruh item mengukur satu faktor saja yaitu perasaan mengenai diri sendiri.

Selanjutnya penulis ingin melihat apakah item tersebut signifikan atau tidak, mengukur faktor yang hendak diukur. Penulis juga ingin menentukan apakah item tersebut perlu di-drop atau tidak. Penulis melakukan uji hipotesis tentang koefisien muatan faktor dari item-item tersebut. Adapun pengujiannya dilakukan dengan melihat nilai t dari tiap-tiap koefisien muatan faktor, seperti pada tabel 3 berikut ini.

\section{Tabel 3}

Muatan Faktor Item Perasaan Mengenai Diri Sendiri

\begin{tabular}{ccccc}
\hline No & Koefisien & Standard Error & Nilai t & Signifikan \\
\hline 1 & 0,69 & 0,12 & 5,97 & $\mathrm{~V}$ \\
4 & 0,22 & 0,09 & 2,50 & $\mathrm{~V}$ \\
7 & 0,03 & 0,09 & 0,38 & $\mathrm{X}$ \\
10 & 0,58 & 0,11 & 5,53 & $\mathrm{~V}$ \\
13 & $-0,05$ & 0,09 & $-0,53$ & $\mathrm{X}$ \\
16 & 0,05 & 0,09 & 0,59 & $\mathrm{X}$ \\
19 & 0,01 & 0,09 & 0,11 & $\mathrm{X}$ \\
21 & 0,09 & 0,09 & 0,71 & $\mathrm{X}$ \\
23 & 0,06 & 0,09 & 0,71 & $\mathrm{X}$ \\
25 & 0,32 & 0,09 & 3,61 & $\mathrm{~V}$ \\
\hline
\end{tabular}

Keterangan: tanda $\mathrm{V}=$ signifikan $(\mathrm{t}>1,96) ; \mathrm{X}=$ tidak signifikan

Pada tabel 3 diatas, dapat dilihat bahwa 4 item signfikan dan semua bermuatan positif. Pada tahap ini 6 item yang akan dieliminasi. Kemudian, pada model pengukuran ini terdapat kesalahan pengukuran item yang saling berkorelasi satu dengan lainnya, artinya item-item tersebut bersifat multidimensional pada dirinya masing-masing dan tidak hanya mengukur satu faktor saja. Hal ini dapat dilihat dari nilai df yang pada awalnya berjumlah 35, namun setelah mencapai model fit, df yang tersisa berjumlah 31. Oleh karenanya terdapat $35-31=4$ korelasi kesalahan yang dibebaskan (lihat gambar 1). Item harus didrop jika memiliki korelasi parsial lebih dari tiga. Karena tidak ada item 
yang memiliki korelasi parsial dengan lebih dari tiga item, maka tidak ada item yang dieliminasi.

Selanjutnya penulis menguji apakah 7 item perasaan mengenai hidup yang ada bersifat unidimensional, artinya benar hanya mengukur faktor yang dilakukan dengan model satu faktor, ternyata tidak fit, dengan chi-square $=67,96, \mathrm{df}=14$, $P$-value $=0.00000$, dan nilai RMSEA $=0.136$. Oleh sebab itu, penulis melakukan modifikasi terhadap model, dimana kesalahan pengukuran pada beberapa item dibebaskan berkorelasi satu sama lainnya seperti pada gambar 2 berikut ini.

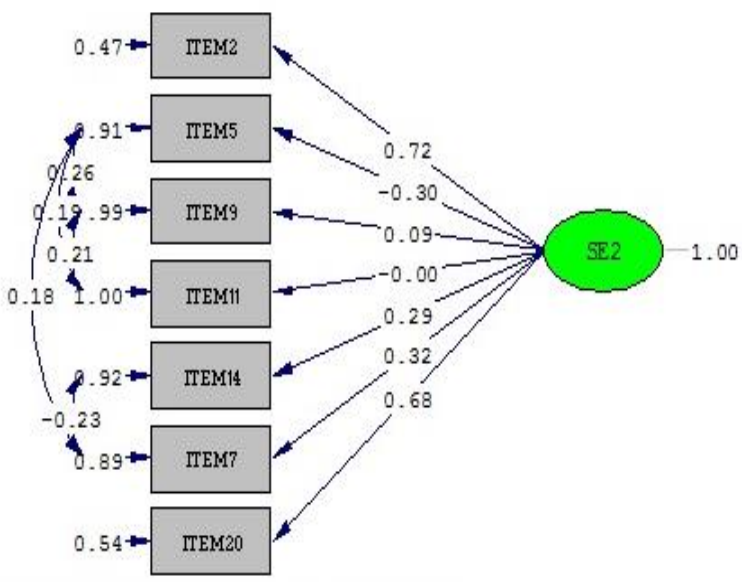

Chi-Square=16.51, df=9, P-value $=0.05698$, RMSEA $=0.063$

\section{Gambar 2}

Analisis Faktor Konfirmatorik Self-Esteem Inventory Dimensi Perasaan Mengenai Hidup

Dari gambar 2 diatas, maka dapat diperoleh model fit dengan chi-square $=16,51, \mathrm{df}=9, P$-value $=0.05698, \mathrm{RMSEA}=0.063$. Nilai chi-square menghasilkan $P$-value $>0.05$ (tidak signifikan), yang artinya model dengan satu faktor (unidimensional) dapat diterima, dimana seluruh item mengukur satu faktor saja yaitu perasaan mengenai hidup.

Selanjutnya penulis ingin melihat apakah item tersebut signifikan atau tidak, mengukur faktor yang hendak diukur. Penulis juga ingin menentukan 
apakah item tersebut perlu di-drop atau tidak. Penulis melakukan uji hipotesis tentang koefisien muatan faktor dari item-item tersebut. Adapun pengujiannya dilakukan dengan melihat nilai t dari tiap-tiap koefisien muatan faktor, seperti pada tabel 4 berikut ini.

\section{Tabel 4}

Muatan Faktor Item Perasaan Mengenai Hidup

\begin{tabular}{ccccc}
\hline No & Koefisien & Standard Error & Nilai t & Signifikan \\
\hline 2 & 0,72 & 0,08 & 8,74 & $\mathrm{~V}$ \\
5 & $-0,30$ & 0,08 & $-3,57$ & $\mathrm{X}$ \\
9 & 0,09 & 0,08 & 1,02 & $\mathrm{X}$ \\
11 & 0,00 & 0,08 & $-0,04$ & $\mathrm{X}$ \\
14 & 0,29 & 0,08 & 3,25 & $\mathrm{~V}$ \\
17 & 0,32 & 0,08 & 3,89 & $\mathrm{~V}$ \\
20 & 0,68 & 0,08 & 3,34 & $\mathrm{~V}$ \\
\hline
\end{tabular}

Keterangan: tanda $\mathrm{V}=$ signifikan $(\mathrm{t}>1,96) ; \mathrm{X}=$ tidak signifikan

Pada tabel 4 di atas, dapat dilihat bahwa 4 item signfikan dan semua koefisien bermuatan positif. Pada tahap ini 3 item yang dieliminasi. Kemudian, pada model pengukuran ini terdapat kesalahan pengukuran item yang saling berkorelasi satu dengan lainnya, artinya item-item tersebut bersifat multidimensional pada dirinya masing-masing dan tidak hanya mengukur satu faktor saja. Hal ini dapat dilihat dari nilai df yang pada awalnya berjumlah 14, namun setelah mencapai model fit, df yang tersisa berjumlah 9. Oleh karenanya terdapat 14-9 = 5 korelasi kesalahan yang dibebaskan (lihat gambar 2). Item harus dieliminasi jika memiliki korelasi parsial lebih dari tiga. Karena tidak ada item yang memiliki korelasi parsial dengan lebih dari tiga item, maka tidak ada item yang dieliminasi.

Selanjutnya penulis menguji apakah 8 item hubungan dengan orang lain yang ada bersifat unidimensional, artinya benar hanya mengukur faktor yang dilakukan dengan model satu faktor, ternyata tidak fit, dengan chi-square $=44,75$, df $=20, P$-value $=0.00119$, dan nilai $\mathrm{RMSEA}=0.077$. Oleh sebab itu, penulis 
melakukan modifikasi terhadap model, dimana kesalahan pengukuran pada beberapa item dibebaskan berkorelasi satu sama lainnya seperti pada gambar 3 berikut ini.

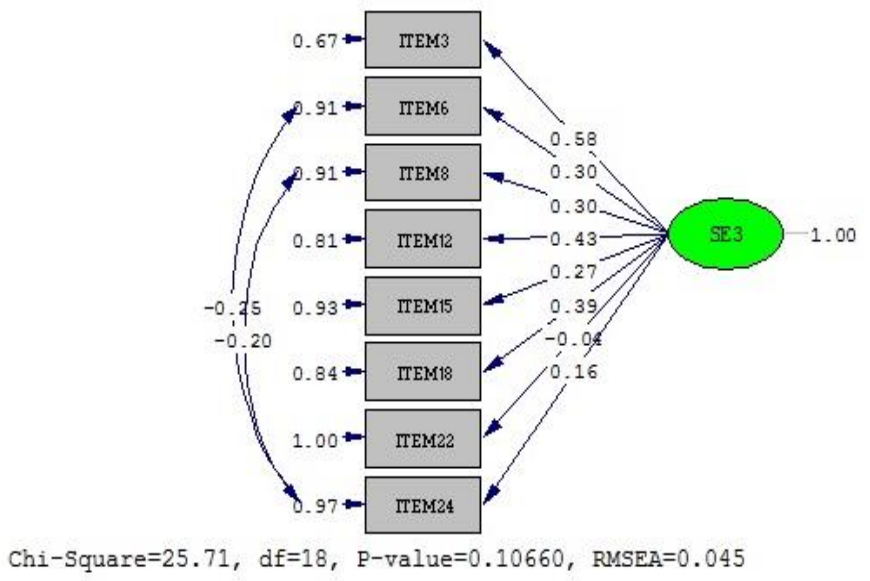

Gambar 3

Analisis Faktor Konfirmatorik Self-Esteem Inventory Dimensi Hubungan dengan Orang Lain

Dari gambar 3 diatas, maka dapat diperoleh model fit dengan chi-square $=25,71 \mathrm{df}=18$, P-value $=0.10660$, RMSEA $=0.045$. Nilai chi-square menghasilkan $P$-value $>0.05$ (tidak signifikan), yang artinya model dengan satu faktor (unidimensional) dapat diterima, dimana seluruh item mengukur satu faktor saja yaitu hubungan dengan orang lain.

Selanjutnya penulis ingin melihat apakah item tersebut signifikan atau tidak, mengukur faktor yang hendak diukur. Penulis juga ingin menentukan apakah item tersebut perlu dieliminasi atau tidak. Penulis melakukan uji hipotesis tentang koefisien muatan faktor dari item-item tersebut. Adapun pengujiannya dilakukan dengan melihat nilai $\mathrm{t}$ dari tiap-tiap koefisien muatan faktor, seperti pada tabel 5 berikut ini. 


\section{Tabel 5}

Muatan Faktor Item Hubungan dengan Orang Lain

\begin{tabular}{ccccc}
\hline No & Koefisien & Standard Error & Nilai t & Signifikan \\
\hline 3 & 0,56 & 0,10 & 5,46 & $\mathrm{~V}$ \\
6 & 0,29 & 0,09 & 3,11 & $\mathrm{~V}$ \\
8 & 0,29 & 0,09 & 3,02 & $\mathrm{~V}$ \\
12 & 0,46 & 0,10 & 4,72 & $\mathrm{~V}$ \\
15 & 0,30 & 0,09 & 3,12 & $\mathrm{~V}$ \\
18 & 0,38 & 0,10 & 3,97 & $\mathrm{~V}$ \\
22 & $-0,02$ & 0,09 & $-0,21$ & $\mathrm{X}$ \\
24 & 0,03 & 0,09 & 0,34 & $\mathrm{X}$ \\
\hline
\end{tabular}

Keterangan: tanda $\mathrm{V}=$ signifikan $(\mathrm{t}>1,96) ; \mathrm{X}=$ tidak signifikan

Pada tabel 5 diatas, dapat dilihat bahwa 6 item signfikan dan semua koefisien bermuatan positif. Pada tahap ini 2 item yang dieliminasi. Kemudian, pada model pengukuran ini terdapat kesalahan pengukuran item yang saling berkorelasi satu dengan lainnya, artinya item-item tersebut bersifat multidimensional pada dirinya masing-masing dan tidak hanya mengukur satu faktor saja. Hal ini dapat dilihat dari nilai df yang pada awalnya berjumlah 20, namun setelah mencapai model fit, df yang tersisa berjumlah 18. Oleh karenanya terdapat 20-18 = 2 korelasi kesalahan yang dibebaskan (lihat gambar 3). Item harus dieliminasi jika memiliki korelasi parsial lebih dari tiga. Karena tidak ada item yang memiliki korelasi parsial dengan lebih dari tiga item, maka tidak ada item yang dieliminasi.

\section{DISKUSI}

Hasil uji validitas konstruk terhadap instrumen self-esteem inventory dengan menggunakan pendekatan confirmatory factor analysis mengungkapkan bahwa 
seluruh item bersifat unidimensional atau dengan kata lain hanya mengukur satu faktor saja, yakni self-esteem (perasaan mengenai diri sendiri, perasaan mengenai hidup dan hubungan dengan orang lain). Dapat disimpulkan bahwa model satu faktor yang diteorikan oleh instrumen self-esteem inventory ini dapat diterima. Hal ini dikarenakan seluruh item instrumen ini memenuhi kriteria-kriteria sebagai item yang baik, yaitu (1) memiliki muatan faktor positif, (2) valid (signifikan, t>1.96), dan (3) hanya memiliki korelasi antar kesalahan pengukuran item yang tidak lebih dari tiga atau dengan kata lain item tersebut bersifat unidimensional.

\section{DAFTAR PUSTAKA}

Minchinton, J. (1993). Maximum Self-esteem. Kuala Lumpur: Golden Books centre SDN.BHD.

Joreskog, K.G. \& Sorbom, D. (1999). LISREL 8.70 for Windows (computer software). Lincoln-wood, IL: Scientific Software International, Inc.

Umar, Jahja. (2011). Bahan kuliah psikometri. UIN Jakarta. Tidak diterbitkan 
